\title{
Label-Free Gene Level Quantification by LC/MS
}

National Cancer Institute

\section{Source}

National Cancer Institute. Label-Free Gene Level Quantification by LCIMS. NCI Thesaurus.

Code C161829.

A method for estimating protein amounts based on gene expression quantitation

analysis in label-free samples subjected to liquid chromatography-mass spectrometry (LC/MS). 